\title{
Poverty Alleviation: The Requisite for Sustainable Development in Nigeria
}

\author{
Anigbogu Theresa* (Ph.D), Ndubuisi-Okolo Purity .U. (Ph.D) \\ Department of Business Administration, Faculty of Management Sciences, Nnamdi Azikiwe University,Awka, \\ Anambra State, Nigeria \\ *Corresponding Author: Anigbogu Theresa, Department of Business Administration, Faculty of \\ Management Sciences, Nnamdi Azikiwe University, Awka, Anambra State, Nigeria
}

\begin{abstract}
Poverty is a critical issue that has threatened the lives of millions of people globally. Its pervasive effect on sustainable development has drastically crippled our economy manifesting itself in abject poverty. It has generated a lot of concerns to the government, private individuals and non-governmental organizations. In view of this, two-fold objectives were formulated: 1.To determine the effect of poverty alleviation on sustainable development in Nigeria and 2.To highlight the causes of poverty in Nigeria. Qualitative research design approach was adopted. Finding revealed that for sustainable development to be achieved, poverty must be eradicated to the barest minimum via entrepreneurship development in terms of skill acquisition and self-development. The study recommended that Nigerian Government needs to honestly ensure that the National Cake is equitably distributed to the three levels of government (Local, State and Federal) and at the same time supervise the disbursement of such funds in order to uphold the theory of equity and fairness in terms of allocation.
\end{abstract}

\section{INTRODUCTION}

Poverty has remained a major bane to sustainable development in Nigeria. Sustainable development is the greatest priority of underdeveloped countries of the world. But this vision has been bedeviled especially in Nigeria by incessant political instability, poor leadership, insecurity, high level of bribery and corruption, decayed educational system, unstable economy etc. All these challenges have crippled Nigerian Economy making it very unstable and our youths have sought for an alternative means of survival by migrating from one country to the other in search of greener pasture.

Poverty is really a malaise confronting the generality of human race. It is perceived as one of the key problems confronting the underdeveloped and developing countries of the world. This is depicted by the statistics of the population living under abject poverty as of 2013, showing a total of 2.47 billion people. The population living under poverty only declined from 2.59 billion to 2.47 billion between 1981 and 2013.That is why poverty is described as a canker worm that has eaten deep into the fabrics of the developing countries of the world.

Poverty occurs as a result of numerous factors ranging from low productivity, poor leadership, uneven distribution of income, economic recession, over reliance on foreign produced goods and paucity of other incentives of entrepreneurship. That is why in the opinion of Alan (2006) the best remedy for poverty alleviation in any country of the world hinges on supporting business activity through entrepreneurship development whereby individuals are empowered to be creative and innovative. This is because creativity and innovation are the two major ingredients of any successful venture as they anchor on initiating novel ideas and putting those ideas into fruition. In the same vein, entrepreneurship creates room for sustainable development which is the basis for economic growth through new knowledge creation and application.

Therefore, sustainable development requires shifts from mundane ways of doing things to a modern ways of executing activities ranging from low to high productivity, the creation and adoption of new goods and services, novel skills and knowledge. It requires entrepreneurship education and knowledge. These shifts are made possible by government at all levels and entrepreneurs who are the architects of "capacity creation" for sustainable development which leads to growth and development; that manifest firmly in high productivity and satisfaction of the inhabitants of the nation. 
Entrepreneurship per sec is a strategy adopted by the government over the years to reduce the adverse effect of poverty in the economy. Entrepreneurial education is, therefore, essential not only to shape the mindsets of young people but also to provide the skills and requisite knowledge necessary to develop an entrepreneurial spirit and culture. Entrepreneurship education provides people with motivation, knowledge, and skills required for launching a successful business venture (Cho, 1998). Developing positive mindsets, good attributes and skills are the basis of achieving entrepreneurial success. Achieving entrepreneurial success is also facilitated by education which is the key to shaping young people's attitudes, skills and culture, Aja-Okorie and Onele Adali (2013). Entrepreneurship education can be achieved not only in schools but also by organizing workshops, seminars for already existing employees in various organizations. When entrepreneurship education is enshrined in the curriculum from primary to tertiary levels, empowerment is assured at all levels of human development. This development reduces poverty and ensures sustainability of Nigerian business environment.

The importance of entrepreneurship cannot be over-emphasized as it serves as a panacea for alleviating poverty cum achieving sustainable development both locally and internationally. It promotes income empowerment in an economy and in the modern world; and also provides a new strategy for combating poverty and stimulating economic growth in developing countries. Entrepreneurship development contributes to poverty alleviation when it creates employment through the startup of new entrepreneurship or the expansion of existing ones, and increases social wealth by developing new markets, new industries, new technology, new institutional forms, new jobs, net increases in real productivity, increase, income which culminates in higher standards of living for the population, Mohammad Delwar Hussain; Abul Bashar Bhuiyan and Rosni Bakar(2014). Therefore, entrepreneurship and youth empowerment are two major strategies for reducing the adverse effect of poverty. Therefore, sustainable development is dependent on the degree to which poverty reduction is achieved among the inhabitants of our nation. In light of the foregoing, this paper sets out to determine the effect of poverty alleviation on sustainable development and it also highlights the causes of poverty in Nigeria.

\subsection{Statement of the Problem}

Sustainable development requires shifts from mundane ways of doing things to a modern ways of executing activities ranging from low to high productivity, the creation and adoption of new strategies, novel skills and knowledge. It requires entrepreneurship education and knowledge. These shifts are made possible by government at all levels, individuals, corporate bodies and entrepreneurs who are the architects of "capacity creation" for sustainable development which leads to growth and development that manifest in high productivity and individual satisfaction.

This great vision has been hampered by incessant political unrest, political instability, abject poverty, poor socio-economic development, teeming population of qualified unemployed youths, lack of entrepreneurial skills, bribery and corruption and numerous other challenges besetting the achievement of sustainable development. This implies that Sustainability is a continuous target which demands urgent attention despite the incessant challenges enumerated above from the leaders and the led.

Therefore, since sustainable development is the dream of any sane person, its non-achievement makes our economy stagnate and creates room for myriads of evils ranging from armed robbery, kidnapping, child trafficking, drug addictions, extortion, etc which go further to aggravate our problems. In the light of the above, this study focuses on the effect of poverty alleviation on sustainable development and the causes of poverty in Nigeria.

\subsection{Objectives of the Study}

Specifically, the study sets out to:

- Determine the effect of poverty alleviation on sustainable development in Nigeria.

- Highlight the causes of poverty in Nigeria

\subsection{Research Questions}

- What is the effect of poverty alleviation on sustainable development in Nigeria?

- What are the causes of poverty in Nigeria?

International Journal of Research in Tourism and Hospitality (IJRTH) 


\section{REVIEW OF RELATED LITERATURE}

\subsection{Conceptual Framework}

\subsubsection{Meaning of Poverty Alleviation and Sustainable Development}

Poverty has remained a major bane to sustainable development and economic growth. The concept has been perceived differently by scholars and corporate organizations. Poverty is seen as a deficiency and degraded human material conditions which hinder the optimal realization of basic human needs such as food, shelter and clothing. This definition implies that poverty has the capacity to deprive individuals of the basic essentials of human existence thereby relegating man to a deplorable state of health and mind. In the opinion of Bello (2006) people living below S100 dollars per day are regarded as poor. That is why the World Bank utilizes the income level of people to evaluate whether they are poor or not. It sets a bench mark of S320 dollars per annum as the poverty line. This depicts that anything below \&320 dollars per annum is a threat to humanity and also a sign of poverty.

The World Commission on Environment and Development (WCED) views sustainable development as "development that meets the needs of the present without compromising the ability of future generations to meet their own needs" (cited in Oyeshola, 2008). Emphasis in this perspective is on sustainable development. There is the need to preserve both human and material resources in the pursuit of development. Therefore, it becomes onus on individuals and corporate organizations to engage in socio-economic activities which are compatible with the needs of man and the environment. According to Ezeanyika (2004) poverty is conceived as the paucity of basic entitlements which could be economic, political or socio-cultural in nature. A critical analysis of this definition showcases that poverty occurs as a result of lack of financial, human and physical necessities capable of creating suitable environment for sustainable living standard. Chambers (1995) sees poverty as a subset of the general condition of deprivation whose dimensions include: social inferiority, isolation, physical weakness, vulnerability, powerlessness and humiliation.

World Bank Development Report (1992) maintains that poverty is the inability to attain a minimum standard of living. World Bank (1999) report aptly defines poverty as a state where an individual is not able to fend adequately for his/her basic needs of food, clothing and shelters; he or she is unable to meet social and economic obligations; lacks gainful employment, skills, assets and self-esteem; has limited access to social and economic infrastructure such as education, health, portable water and sanitation; and consequently has limited chance of advancing his/her welfare to the limit of his/her capacities. This definition is in sync with Eminue (2005) and Landis (1980) perception of Poverty as a state where an individual is not able to cater adequately for his or her basic need of food, clothing and shelter, is unable to meet social and economic obligation; lacks gainful employment, skills, assets and self esteem; and has limited access to social and economic infrastructure such as education, health , potable water and sanitation; and consequently, has limited opportunity of advancing his/her welfare to the limit of his/her capacities.

\subsection{The Effect of Poverty Alleviation on Sustainable Development}

Poverty is a major obstacle to sustainable development in our country. The socio-economic situation in Nigeria poses serious threats and challenges to both government and well-being of citizens of the nation as a whole. The unemployment problems further call for different strategies and actions for it to be ameliorated. Entrepreneurship education has been embraced by almost all the developed countries and its capabilities and efficacy in springing up economies is not in doubt. It is believed that refocusing education system will immensely contribute in developing the spirit and culture of entrepreneurship in the country thereby creating avenue for sustainable development in the country.

Entrepreneurial education is essential not only to shape the mindsets of young people but also to provide the skills and knowledge that are central to developing an entrepreneurial culture. Entrepreneurship education provides students motivation, knowledge, and skills essential for launching a successful venture company (Cho, 1998). Developing mindsets, generic attributes and skills that are the foundations of entrepreneurship can be achieved through indoctrination from an early age; that is, if it is incorporated into the national educational system with the seriousness it deserves. Because education is key to shaping young people's attitudes, skills and culture, it is vital that entrepreneurial education is addressed from an early age and up into higher levels of education such as in the universities. Entrepreneurship education should be available to all college students 
regardless of major courses and choice of studies to enhance competitive advantage, not only for students but also the societies and nations where they are involved. The relationship between education and sustainable development has been established, such that education is now internationally accepted as a key development index. The importance of education cannot be overemphasized; it is a fundamental human right, hence, the need for incorporating entrepreneurship in the educational system. Therefore, for sustainable development to be achieved, poverty must be eradicated to the barest minimum via entrepreneurship development.

\subsection{Causes of Poverty in Nigeria}

Poverty is a critical issue that has threatened the lives of millions of people globally. Its pervasive effect on sustainable development has drastically crippled our economy manifesting itself in abject poverty. It has generated a lot of concerns to the government, private individuals and nongovernmental organizations. According to Obi, Nwachukwu and Obiora (2008), Burkey (1993) and Eneh (2011) in Nkwede(2013) the causes of poverty, especially in Nigeria include: low productivity, market imperfections, environmental degradation, lack of modernization tendencies, physical limitations, bureaucratic stiffing, dependency on third world countries, income inequalities, laziness, illiteracy, increased population, hunger, lack of industry, exploitation, lack of initiative, low productivity, lack of skills, economic underdevelopment, non implementation of policies and programmes, corruption, political instability, social conflict, weak governance, mismanagement, unemployment and ignorance. Joseph (2006) also pointed out that what contributes to poverty include: family size, low level of human capital, inaccessibility to cultivable land, lack of all weather roads, poor access to market and slow endowment of human capital. Other causes of poverty in Nigeria include: Poor health status of citizens, family structure (Polygamy) ignorance, economic crisis, culture and social values (Nkwede, 2010). In tandem with the multifaceted causes of poverty by scholars and researchers, other causes of poverty in Nigeria include poor leadership, religious beliefs, family background, poor parental upbringing, peer influences, laziness etc.

Poor leadership: Primarily, poor leadership has kept Nigerians in a perpetual state of infancy for ages. The virus inflicting pains on us is our political leaders. The import of this statement is that old men and women with paucity of vision have tarnished the dreams of Nigerians. The leaders without portfolio and profundity to pilot the affairs of this great nation are occupying strategic positions in the political arena making life miserable and unbearable for the poor masses. What do we now do to remedy this anomaly? Nigerian leaders take note!

Religious beliefs: Religion has crippled some people financially because every genuine business becomes sin in the name of Christianity. Some people spend their precious time in their various churches praying for miracles without any dint of hard work. The Bible clearly states that there is no food for a lazy man. Let the so-called men and women of God engage in one form of business or the other in order to fend for their families since manna does not fall from heaven.

Family Background: This element has relegated so many talents to the background. That is why I do personally tell people that poverty is a curse and is not deserving of any man. But despite people's backgrounds, one can still make it to the top depending on one's level of vision, determination and commitment.

Poor parental upbringing: Many parents contributed their quotas to the life challenges their children are passing through today. Some over pampered their children via the adoption of handful of housemaids to pilot the affairs of their homes. This has led to the production of non-challant children who exhibit lackadaisical attitudes towards every human endeavour thereby bluntly leaning on acquired wealth for survival.

Peer influences: This is a real virus inflicting long-life regrets in the mouth of those who could have ordinarily become giants without much ado. Peer influences have maimed and destroyed great talents and stars. Poverty-stricken citizens are most often times are men and women of substance who have misused their God-given talents and rare opportunities.

\subsection{Theoretical Framework}

The study relies on Human Capital Theory developed by Robert (1991). He proposes that education is a tool for enhancing human capital development, achieving sustainable development, reducing poverty, skyrocketing labour productivity and boasting the levels of technology both locally and 
internationally. According to the theory, human capital improvement through quality education and training is a critical factor that propels economic growth and sustainable development in many parts of the countries. Human capital can have major effects on an individual's risk of poverty or success. It was indicated that human capital significantly affects people's earning, and consequently lack of human capital can place an individual at risk of poverty. Therefore, in a bid to alleviate poverty, human elements need to be developed via entrepreneurship education to acquire the necessary skills. In the opinion of Rank (2004) and Darling (2002), individuals with greater human capital are more likely to be competitive in the labor market than those who lack human capital. Human capital is seen as a set of skills that increase workers' productivity and performance in any organization. Human capital has played a major significant role in economic development, productivity, education, growth and innovation which has been stated as a justification for government subsidies for education and job skills training. Human capital improvement through quality education and training is a critical factor that propels economic growth and development in Nigeria.

The theory is crucial to this study because it stresses that when people acquire quality education and skill training, they will contribute to economic growth and development which in turn creates room for sustainable development by establishing and managing new venture, creating employment which will improve the standard of living of the people. This implies that poverty will be called to extinction.

\subsection{Empirical Review}

Iwala Oladapo Sam (2014) studied Achieving Sustainable Poverty Reduction and Rural Development in Nigeria through Local Economic Development Strategies. This research brought to limelight that all around the world, local governments, the private sector and even the civil society are exploring better ways to achieve poverty reduction and rural development through local economic development strategies. This is sequel to the fact that local governments, particularly in Nigeria face increased challenges of poor quality leadership, financial indiscipline, almost absolute reliance on allocation from the federal government account / meager internally generated revenues, pervasive poverty, income inequality, long-term ethnic conflict and civil unrest, political instability and corruption among others. This study showcases local economic development strategies, as a participating process in which local people from all sectors work together to help create decent jobs and improve the quality of life for everyone, including the poor and marginalized as the most potent tool for achieving sustainable poverty reduction and rural transformation in Nigeria.

Ogbo, A. I.1, Eneh, Nnajiofor C. J.1, Agbaeze E. K.1, Chukwu, B. I.1and Isijola, D. O.(2017) focused on the strategies for achieving sustainable economy in Nigeria taking into consideration the acceptable stakeholders. This work looks at the explosion of the Nigerian population from the year 2005 till date, the modern state of the Nigerian economy and the failed strategies adopted in the past, with a critical look at the acceptable stakeholders, sustainable economy, and the strategic priorities to be considered in the Nigerian context. Theories of modernization (showing the five take off stages), sustainable development, and human development (with the five key capitals) were used to analyze the problem of achieving a sustainable economy in Nigeria. The triple-bottom-line strategy was seen to be a possible solution to the impending problem of unstable economy in Nigeria, intending to social responsibility, environmental protection, and economic priority.

Mohammad Delwar Hussain; Abul Bashar Bhuiyan and Rosni Bakar(2014) conducted study on entrepreneurship development and poverty alleviation in Malaysia. The sole aim of the paper was to corroborate the relationship between entrepreneurship development and poverty alleviation built on empirical reviews. In this study, a general search was carried out to accumulate empirical literatures by the name of entrepreneurship development and poverty alleviation in different online database sources such as Google Scholars, Springer Link, Wiley, Science Direct, JSTOR, Emerald full text, Scopus, and EBSCO HOST etc. The empirical findings revealed that innovation, entrepreneurship training \& education, family background, government support program, social entrepreneurship, women participation, individual entrepreneurial characteristics, participation of micro, small \& medium enterprises, youth empowerment; collaboration of government-university-industry is the main tool for entrepreneurship development which is stimulating employment towards alleviating poverty.

Uzoma Aja-Okorie and Onele Adali (2013) investigated achieving youth empowerment through repositioning entrepreneurial education in Nigerian universities: Problems and Prospects. They stated 
that the overall goal of entrepreneurial education is to impart on students and youths the right attitudes, knowledge and skills to act in an entrepreneurial manner. Thus, empowering and preparing them to thrive in the unstructured and unpredictable environment saddled with unpleasant surprises. This paper therefore, examines the relevance of entrepreneurial education in achieving youth empowerment in Nigeria; the challenges facing entrepreneurial education in universities and prospects. The reasons for entrepreneurship education as well as strategies for designing entrepreneurship education. This paper concludes that entrepreneurial education deserves not only to be addressed at tertiary level but also should be incorporated at all levels of education for an allencompassing model and in achieving desired goals and ensuring self-reliance among Nigerian youths,

Ndubuisi-Okolo, Anigbogu and Leonard Onwuzuligbo (2015) researched on entrepreneurship Education and Youth Development in Nigeria: The Challenges. The thrust of this piece of write-up is to examine the effect of entrepreneurship education on youth development in Nigeria. The study adopted human capital Theory advocated by Robert (1991).Secondary data were the major instruments used for data collection. Objectives were articulated to investigate challenges militating against success of entrepreneurship education in Nigeria and also how entrepreneurship education can assist in nation building .It was concluded that through well-planned and executed entrepreneurship education, the Nigerian youths will learn to be happy and fulfilled, as they will be more productive and committed as employees or employers of labour; thereby allowing their unique capabilities to be utilized for the development of the national and global goals rather than abandoning their country for greener pastures overseas. It was also recommended that entrepreneurship education should be incorporated into the ongoing career preparation programs in secondary schools, colleges of education, polytechnics and universities, since it is imperative that the country's workforce have entrepreneurial skills and attitudes before they enroll in employment, whether as employers or employees in order to compete effectively and efficiently in the marketplace nationally and globally.

\section{Methodology}

This piece of work adopted a qualitative approach in an attempt to determine the effect of poverty alleviation on sustainable development and the causes of poverty in Nigeria. The source of material for the study was secondary in nature via internet, textbooks and other documents relevant to this study.

\section{COnClusion And Policy Recommendations}

It is very transparent that sustainable development is only attained when the welfare of the poor masses are taken into consideration. This implies striking a balance between the rich and the poor. Therefore, the following policy recommendations are made:

- The Nigerian Government needs to honestly ensure that the National Cake is equitably distributed to the three levels of government (Local, State and Federal) and at the same time supervise the disbursement of such funds in order to uphold the theory of equity and fairness in terms of allocation.

- Entrepreneurship education should be made available to primary school pupils, all college students and University Undergraduates regardless of their major courses and choice of studies to enhance their competitive abilities. This is because Entrepreneurship Education provides students with the requisite motivation, knowledge, and skills relevant for launching a successful venture.

- We need to restructure our political structure to incorporate all the necessary ingredients that will enable us to fight poverty to the barest minimum.

- Individuals and corporate organizations need to engage in socio-economic activities which are compatible with the needs of man and the environment geared towards self-development and selfreliance.

- Leadership in Nigerian should be based on integrity, honesty, equity and qualification and not on marginalization, rigging, victimization, and tribalism to ensure that right people are voted into power. This is because when people with right mindsets are voted into power, the economy automatically becomes favourable for the citizenry. 


\section{REFERENCES}

[1] Bello, M. (2006) "Reflections on Poverty Reduction Strategies" in A Saliu et al, (EDS) Democracy and Development in Nigeria.) Economic and Environmental Issues. Lagos: Concept Publishers, 8(2).

[2] Cho, B. (1998).Study of the effective entrepreneurship education method and its process". Business Education Research. 2(1):27-47.

[3] Iwala Oladapo Sam (2014). Achieving Sustainable Poverty Reduction and Rural Development in Nigeria through Local Economic Development Strategies.” American Journal of Rural Development 2(1): 13-19.

[4] Mohammad Delwar Hussain; Abul Bashar Bhuiyan and Rosni Bakar(2014). Entrepreneurship development and poverty alleviation. Journal of Asian Scientific Research, 2014, 4(10): 558-573.

[5] Ogbo, A. I.1, Eneh, Nnajiofor C. J.1, Agbaeze E. K.1, Chukwu, B. I.1and Isijola, D. O.(2017). Strategies for achieving sustainable economy in Nigeria taking into consideration the acceptable stakeholders. African Journal of Business Management, 11(19): 582-589.

[6] Oyeshola, P. (2008) Sustainable Development: Issues and Challenges for Nigeria. Ibadan: Daily Graphics Nigeria Limited.

[7] Uzoma Aja-Okorie and Onele Adali (2013).Achieving youth empowerment through repositioning entrepreneurial education in Nigerian universities: problems and prospects. European Scientific Journal 9(28), 114-131.

[8] Ndubuisi-Okolo Purity Uzoamaka, Theresa Anigbuogu and Leonard Onwuzuligbo (2015). Entrepreneurship Education and Youth Development in Nigeria: The Challenges. International Journal of Current Research and Academic Review 3( 3) ,229-242.

[9] Nkwede Joseph O.(2013). Approaches for Poverty Alleviation and Sustainable Development in Nigeria: International Journal of Social Science Studies 2(1).

Citation: Anigbogu Theresa. "Poverty Alleviation: The Requisite for Sustainable Development in Nigeria ". International Journal of Research in Tourism and Hospitality (IJRTH), vol 5, no. 1, 2019, pp. 16-22. doi: http://dx.doi.org/10.20431/2455-0043.0501003.

Copyright: (C) 2019 Authors. This is an open-access article distributed under the terms of the Creative Commons Attribution License, which permits unrestricted use, distribution, and reproduction in any medium, provided the original author and source are credited. 